\title{
Phytophthora Shuck and Kernel Rot, a New Disease of Pecan Caused by Phytophthora cactorum
}

\author{
C. C. Reilly, Research Plant Pathologist, USDA-ARS, Southeastern Fruit and Tree Nut Laboratory, Byron, GA \\ 31008; and M. W. Hotchkiss, Former Graduate Student, and F. F. Hendrix, Jr., Professor Emeritus, Department of \\ Plant Pathology, University of Georgia, Athens 30602-7274
}

\begin{abstract}
Reilly, C. C., Hotchkiss, M. W., and Hendrix, F. F., Jr. 1998. Phytophthora shuck and kernel rot, a new disease of pecan caused by Phytophthora cactorum. Plant Dis. 82:347-349.

Phytophthora shuck and kernel rot infection usually started at the stem end of the pecan fruit and progressed distally to encompass the entire shuck within 4 to 6 days. A distinct margin developed between dark brown necrotic tissue and healthy green tissue during rotting of the shucks. Phytophthora cactorum was isolated from the rapidly rotting pecan fruit. Two to three weeks after the symptoms appeared, the diseased shucks dried and stuck tightly to the shell. The seed coat of the kernel turned dark brown and the endosperm rotted. The new disease of pecan was first observed during September 1988 on maturing pecan fruit in central Georgia in the vicinity of the town of Byron where growers estimated losses of $50 \%$ or greater in some orchards. In south Georgia near the cities of Albany and Cordele, the disease was present but less severe. The causal agent was identified as P. cactorum and deposited with ATCC as isolate B1, ATCC No. 66186. Laboratory and field inoculations of nut clusters using the B1 isolate produced typical symptoms observed in nature. Symptoms of the disease were observed in 13 orchards, and the pathogen was isolated from the soil of 10 of these orchards in south and central Georgia.
\end{abstract}

Additional keywords: Carya illinoensis, fruit rot, shuck decline

An extremely rapid and distinctive rot of pecan (Carya illinoensis (Wangenh.) C. Koch) fruit was observed throughout central Georgia in September 1988. Symptoms of the disease were seen first near the town of Byron in mid-September after a prolonged period of rain. The shucks of mature pecan fruit turned dark brown to black and were totally rotted. During cool and wet periods of 2 to 3 days during mid- to late September, a whitish gray film, later identified as mycelium of the pathogen, developed over the rotted shuck tissue.

Georgia is the leading state in pecan culture, producing $38.4 \%$ of the national total, averaging 49.8 million $\mathrm{kg}$ in-shell production valued at $\$ 79.7$ million annually (15). Yield losses due to shuck and kernel rot in some orchards of central Georgia were estimated by the growers to be $50 \%$ or greater, with further monetary

Corresponding author: C. C. Reilly

E-mail: a03nuts@attmail.com

Accepted for publication 26 November 1997.

Publication no. D-1997-1222-01R

This article is in the public domain and not copyrightable. It may be freely reprinted with customary crediting of the source. The American Phytopathological Society, 1998. losses caused by poor quality of the surviving fruit. The disease appeared on most of the major cultivars of pecan grown in the southeastern United States, including the top three cultivars-Stuart, Desirable, and Schley (1). This disease was present to a lesser extent in other pecan-producing areas of the state.

The disease was new to pecan culture. This work was undertaken to describe the occurrence and symptoms of the disease and identify the pathogen. Disease notes suggesting the name "Phytophthora shuck and kernel rot" were published $(11,12)$ to alert scientists and concerned producers.

\section{MATERIALS AND METHODS}

Orchard selection. Pecan extension specialists and individual growers brought to our attention a fruit disorder of unknown origin during September and October 1988. Fruit and soil samples were collected from 13 disease-affected orchards in the major pecan production areas in south and central Georgia. Five of the affected orchards were near the city of Albany and four were near Cordele, both in south Georgia, and four were within a radius of $15 \mathrm{~km}$ of Byron in central Georgia. The disease appeared only in irrigated orchards that were well managed according to recommendations (1) and was not observed in non-irrigated orchards. All orchards contained mature (older than 25-30 years) trees, primarily of Stuart and Schley cultivars.

Isolation and identification of the pathogen from fruit. Diagnostic fruit isolations were conducted primarily on Schley, a cultivar widely planted throughout Georgia, but affected fruits of Stuart and Desirable were also assayed to confirm the disease on other cultivars. To isolate and identify Phytophthora cactorum (Lebert \& Cohn) Schroeter, surface disinfested pieces $(5 \mathrm{~mm} \times 5 \mathrm{~mm})$ from the shuck were aseptically removed at the margin of infection and placed on acidified $(0.5 \mathrm{ml}$ of lactic acid per liter of medium, $\mathrm{pH}$ 5.0) Difco potato-dextrose agar (APDA) and incubated at $25^{\circ} \mathrm{C}$ for 4 days. Surface disinfestation was accomplished by washing the fruit in deionized water, then soaking them for $30 \mathrm{~s}$ in $70 \%$ ethanol prior to making isolations. The resulting growth of mycelium on APDA was then subcultured to carrot juice agar (CJA) (15 $\mathrm{g}$ of Difco agar and $354 \mathrm{ml}$ of canned carrot juice per liter) and incubated as described above. Media prepared for the identification of the pathogen included clarified V-8 agar (20 g of Difco agar, $4.5 \mathrm{~g}$ of $\mathrm{CaCO}_{3}$, and $200 \mathrm{ml}$ of $\mathrm{V}-8$ juice per liter clarified by centrifugation at $3,000 \mathrm{rpm}$ for $10 \mathrm{~min}$ ) (CV-8), lima bean agar (20 g of Difco agar, 1 liter of lima bean filtrate prepared from $285 \mathrm{~g}$ of frozen lima beans boiled in 2 liters of distilled water for $1 \mathrm{~h}$ then filtered through cheesecloth) (LBA), and Difco cornmeal agar (CMA).

Inoculation studies. Pecan fruit clusters were inoculated with isolate B1, which was isolated from a Schley fruit at the USDA-ARS Southeastern Fruit and Tree Nut Laboratory at Byron and deposited with the American Type Culture Collection (ATCC) as ATCC No. 66186. Either mycelial plugs or a mycelial suspension was used for the inoculations. Two inoculation methods were used in the laboratory. The first method used 6 detached Schley fruit clusters, containing 3 to 4 fruit per cluster, that were washed with running deionized water for $5 \mathrm{~min}$. Residual water from the washing was air dried from the fruit surfaces and a 6-mm-diameter hole was punched into the shuck using a cork borer. A 6-mm mycelial plug, obtained from a 6day-old CJA culture, was placed in the 
hole, mycelium down, and the fruit clusters were placed into a dark moist chamber for 4 days at $24^{\circ} \mathrm{C}$ and $>90 \% \mathrm{RH}$. A similar number of fruit were treated in the same manner, except sterile CJA plugs were placed in the wound.

The second method used 6 detached Schley fruit clusters, containing 3 to 4 fruit per cluster, that were washed as previously described and placed into moist chambers. A suspension of $P$. cactorum mycelial fragments, prepared by homogenizing a 6day-old CJA culture in $100 \mathrm{ml}$ of sterile water with a Waring blender for $15 \mathrm{~s}$, was applied with an atomizer. Non-inoculated fruit clusters were treated in a similar manner but sprayed only with sterile water.

Twelve fruit clusters per treatment (check and inoculated) having three nuts per cluster of a late maturing pecan seedling at Byron were inoculated in the field on 14 and 24 October 1988. The technique was similar to the laboratory method using the 6-mm punch with the exception of washing of the fruit prior to the inoculation. The fruit clusters remained attached to the tree, sprayed with deionized water, and high humidity was maintained by loosely placing a clear plastic bag over the fruit for $48 \mathrm{~h}$ immediately after inoculation. No attempt was made to shade the treatments from direct sunlight.

Isolations of the pathogen from the soil. The method of Hendrix and Campbell (5) was used to isolate $P$. cactorum from the soil. Soil samples were obtained at four quadrants under the drip line of mature trees. Three trees per orchard were sampled in each of the 13 orchards visited. From each of the quadrants, about $500 \mathrm{~cm}^{3}$ of soil was taken from a depth of 1-20 cm; the four quadrant samples were pooled, mixed, sifted through hardware cloth (6 $\mathrm{mm}^{2}$ mesh), and a small portion placed into two 10-mm-diameter $\times$ 4-cm-deep wells cut into an apple (cv. Golden Delicious). Five apples per sample were prepared in this manner. Infected fruit vascular tissue at the margin of the necrosis was removed aseptically and placed on APDA plates. The resulting fungal growth was transferred to CJA for identification.

\section{RESULTS}

Symptoms. Symptoms of shuck and kernel rot were first observed early in September 1988 in central Georgia. The disease occurred in the canopy of mature pecan trees and appeared more pronounced in orchards with poor drainage and tree crowding. Sequential observations of individual fruit clusters suggested that infections occurred initially on single fruit clusters and moved down the canopy due to rain splash. The fruit cluster serving as the locus of infection was smaller than surrounding fruit, suggesting earlier infection. Pecan shucks turned dark brown within 4 to 6 days of observing the initial necrosis. Apparently, necrosis usually de- veloped first at the attachment end of the fruit. The edge of the diseased area was light brown and possessed a distinct margin, whereas older infected areas turned dark brown and were moist and spongy. Necrosis encircled the shuck and progressed rapidly to the distal end of the fruit. After about 2 weeks, shucks dried, forming a "stick tight" where the shuck remained firmly attached to the shell surface.

The necrosis extended into the kernel, usually from the attachment end of the fruit. The seed coat of the kernel turned dark brown to black and the endosperm became gray and decomposed, resulting in a total loss of the kernels. A white mat of mycelium was commonly observed on the blackened seed coat of affected kernels. The kernels of fruits infected later in the season (October-November) did not decay but had dark brown patches covering more than $25 \%$ of the kernel surface. These kernels were difficult to separate from healthy kernels at the shelling plants and resulted in reduced quality for the entire lot of pecans (F. Weatherbee, Nut Tree Inc., Albany, GA, personal communication).

Identification of the pathogen. $P$. cactorum was isolated consistently on APDA from active margins of the diseased areas of the shuck and kernels. With fruit that had been infected for long periods and had formed "stick tights," $P$. cactorum was difficult to isolate from shucks because other organisms predominated. The additional genera of fungi isolated from the stick tights included species of Alternaria, Botryosphaeria, Fusarium, Penicillium, Pestalotia, and Phoma.

The isolates identified as $P$. cactorum exhibited a rosetting pattern of mycelial growth on APDA, which is characteristic for the species (unpublished data). The rosette pattern of mycelial growth also developed on LBA and CJA but not on CMA. Further identification was made according to Ho (6) and Newhook et al. (10). On LBA or CV-8, sporangia were deciduous, pedicillate $(<5 \mu \mathrm{m})$, broadly ellipsoidal or ovoid, $25.3-33 \mu \mathrm{m} \times 33-39.6$ $\mu \mathrm{m}$ (mean $28.9 \times 33.5 \mu \mathrm{m}$ ), with one apical papilla. Oogonia were abundant in single culture on LBA, CJA, and CV-8, 25-32 $\mu \mathrm{m}$ (mean $28 \mu \mathrm{m}$ ). Oospores were 20.4-25.5 $\mu \mathrm{m}$ (mean $23.2 \mu \mathrm{m}$ ). Antheridia were paragynous. A typical culture isolated from pecan fruit at Byron was submitted to the mycology identification unit USDA-ARS, Beltsville, MD, for confirmation. Subsequently, the fungus was deposited with the American Type Culture Collection as $P$. cactorum isolate B1 from pecan ATCC No. 66186.

Inoculations of pecan fruit. All fruit of each detached cluster were infected and developed the characteristic disease symptoms within 4 to 6 days when CJA plugs with mycelium of the pathogen were inserted into wounded shucks. The edge of the inoculated area was light brown and possessed a distinct margin, whereas older infected areas turned dark brown and were moist and spongy as the symptoms developed. The fungus was reisolated from the edge of all infected areas. Infection did not occur on the fruit clusters that were wounded and fitted with sterile CJA plugs, nor was the fungus isolated from the shuck tissue. Similarly, the disease symptoms also developed on all fruit clusters when mycelial fragments were sprayed onto the shuck surface, but there were no clear margins of infection because the entire fruit was sprayed. None of the clusters sprayed with sterile water developed symptoms. Thus, wounds were not necessary for infection to occur.

In the field inoculations, typical symptoms as observed on detached fruit fitted with mycelial plugs were produced. Field inoculations were initiated in late October and symptoms developed at a slower rate (6-10 days) compared to the 4-6 days of development observed in September and in laboratory inoculations. The difference in temperature between September and late October may account for the slower rate. The average maximum and minimum air temperatures at $1.5 \mathrm{~m}$ (USDA, Byron, GA Weather Station) for 1-15 September were 24.4 and $17.8^{\circ} \mathrm{C}$, respectively. For the inoculation periods of 14-21 October, average maximum and minimums were 23.3 and $6.6^{\circ} \mathrm{C}$, respectively, and for 24 to 31 October were 22.8 and $9.4^{\circ} \mathrm{C}$, respectively. The fungus was isolated from the inoculated fruit but not from the wounded checks.

Isolation of the pathogen from soil. The overall frequency of isolation of the pathogen from soil was low, ranging from 3.3 to $30 \%$ (Table 1). P. cactorum was detected in the soil in 10 of the 13 orchards sampled. Disease symptoms on the fruit

Table 1. Isolation of Phytophthora cactorum from pecan orchard soils from south, south central, and central Georgia

\begin{tabular}{|c|c|c|}
\hline $\begin{array}{l}\text { Region and } \\
\text { county }\end{array}$ & $\begin{array}{l}\text { Orchard } \\
\text { number }\end{array}$ & $\begin{array}{l}\text { Frequency of } \\
\text { isolation }(\%)^{\mathrm{a}}\end{array}$ \\
\hline \multicolumn{3}{|c|}{ South Georgia } \\
\hline \multirow[t]{2}{*}{ Mitchell } & 1 & 3.3 \\
\hline & 2 & 23.3 \\
\hline \multirow[t]{3}{*}{ Lee } & 1 & 0.0 \\
\hline & 2 & 3.3 \\
\hline & 3 & 3.3 \\
\hline \multicolumn{3}{|c|}{ South central Georgia } \\
\hline \multirow[t]{2}{*}{ Sumter } & 1 & 0.0 \\
\hline & 2 & 3.3 \\
\hline \multirow[t]{2}{*}{ Crisp } & 1 & 10.0 \\
\hline & 2 & 0.0 \\
\hline \multicolumn{3}{|c|}{ Central Georgia } \\
\hline \multirow[t]{2}{*}{ Peach } & 1 & 16.7 \\
\hline & 2 & 23.3 \\
\hline Macon & 1 & 30.0 \\
\hline Houston & 1 & 3.3 \\
\hline
\end{tabular}

${ }^{a}$ Frequency of isolation based on three samples per orchard. Each sample was placed into five apples each containing two wounds of $10 \mathrm{~mm}$ in diameter. 
were observed in all of the 13 orchards from which the soil samples were collected.

\section{DISCUSSION}

$P$. cactorum was isolated from pecan fruit and orchard soils near Albany, Cordele, and Byron, GA. This pathogen caused a shuck and kernel rot of pecan late in the season, as nuts were maturing. We have proposed that this new, late season disease be named "Phytophthora shuck and kernel rot of pecans" $(11,12)$.

Changes in pecan culture and environmental factors may have favored the development of Phytophthora shuck and kernel rot. During the 2 years prior to 1988 , a reduced fungicide spray program for the management of pecan scab caused by Cladosporium caryigenum has been recommended in Georgia $(1,4)$. The number of fungicide sprays were reduced by one or two applications by applying the last treatment in early August as compared to the extended program, which ended in late September. Fentin hydroxide (SuperTin), the primary fungicide for late season pecan scab control, has partial efficacy against $P$. cactorum $(7,8)$. Thus, pecan fruit were not protected against this pathogen when it appeared late in the season.

A cultural factor that may have influenced the development of this new disease was the increase of irrigation. About 50\% of production orchards are under solid set or drip irrigation systems (9), and shuck and kernel rot was found only in irrigated orchards. Increased soil moisture during normally dry periods in August and September would tend to favor survival and dispersal of the pathogen $(2,14)$.

Environmental factors that were involved in the development of this disease were prolonged periods of cool moist weather and heavy dews in the late growing season. During 1988, middle Georgia received showers and thunderstorms during August and then in early September a hurricane indirectly influenced the weather for
6 days with cool, wet, and overcast conditions. Rainfall occurred on 11 of 15 days between 28 August and 11 September (USDA, Byron, GA, Weather Station). These weather conditions, both low temperature and excessive precipitation, were highly atypical of the 25-year average at the Byron station. Immediately after this period, symptoms of the disease were first noticed. Fruit rot caused by $P$. cactorum on other plant species occurs during similar cool and wet weather conditions $(3,13)$. More recently, $P$. cactorium was detected on pecan fruit during 1994, but only to a minor extent, and attempts were unsuccessful during all other seasons from 1989 through 1996.

Under normal conditions, $P$. cactorum is a soil pathogen. It is uncertain how this organism could appear in the crown of a 18- to 24-m-tall tree. Direct rain splash from the ground upward to this height was considered to be unlikely. Symptoms were not observed on much of the fruit on the lower branches, but higher in the canopy large patches of diseased fruit developed. The pattern of disease development in the tree canopy indicated that initial infection probably occurred on a few nut clusters and then spread from those points during periods of rain. The nut clusters initially infected were visibly smaller and in an advanced "stick tights" state of disease development as compared with adjacent infected fruit. The small size would indicate that growth probably stopped when infection occurred, 2 to 3 weeks prior to the epiphytotic. The method by which the pathogen moved into the tree canopy, suspected to involve insect vectors, has been investigated further, but no conclusions have been reached.

\section{ACKNOWLEDGMENTS}

We acknowledge S. C. Redlin, contract scientist, Systematic Botany and Mycology Laboratory, Beltsville, MD, and H. H. Ho, Department of Biology, State University of New York, New Paltz, $\mathrm{NY}$, for their assistance in confirming the identification of Phytophthora cactorum.

\section{LITERATURE CITED}

1. Crocker, T. F. 1986. Commercial pecan production. GA Coop. Ext. Ser. Bull. 609.

2. Duniway, J. M. 1983. Role of physical factors in the development of Phytophthora diseases. Pages 175-187 in: Phytophthora: Its Biology, Taxonomy, Ecology, and Pathology. D. C. Erwin, S. Bartnicki-Garcia, and P. H. Tsao, eds. American Phytopathological Society, St. Paul, MN.

3. Ellis, M. A., and Grove, G. G. 1983. Leather rot in Ohio strawberries. Plant Dis. 67:549.

4. Gottwald, T. R., and Bertrand, P. F. 1988. Effects of an abbreviated pecan disease control program on pecan scab disease increase and crop yield. Plant Dis. 72:27-32.

5. Hendrix, F. F., and Campbell, W. A. 1970. Distribution of Phytophthora and Pythium species in soils in the continental United States. Can. J. Bot. 48:377-384.

6. Ho, H. H. 1981. Synoptic keys to the species of Phytophthora. Mycologia 73:705-714.

7. Hotchkiss, M. W., and Reilly, C. C. 1991. Evaluations of fungicides for control of Phytophthora shuck and kernel rot, 1990. Fungicide Nematicide Tests 46:85.

8. Hotchkiss, M. W., and Reilly, C. C. 1992. Evaluations of fungicides for control of Phytophthora shuck and kernel rot, 1991. Fungicide Nematocide Tests 47:71.

9. Hubbard, E. E., Purcell, J. C., and Crocker, T. F. 1988. Commercial pecan tree inventory and prospectus, Georgia, 1987. Univ. Ga. Agric. Exp. Sta. Res. Rep. 554.

10. Newhook, F. J., Waterhouse, G. M., and Stamps, D. J. 1978. Tabular key to the species of Phytophthora DeBary. Mycol. Papers, No. 143.

11. Reilly, C. C. 1989. Late season diseases of pecan. Proc. Southeastern Pecan Growers Assoc. 82:67-70.

12. Reilly, C. C., Hendrix, F. F., Jr., and Hotchkiss, M. W. 1989. First report of Phytophthora cactorum causing a shuck and kernel rot of pecan fruit. Plant Dis. 73:701.

13. Rose, D. H. 1926. Relation of strawberry fruit rots to weather conditions in the field. Phytopathology 16:229-232.

14. Weste, G. 1983. Population dynamics and survival of Phytophthora. Pages 237-257 in: Phytophthora: Its Biology, Taxonomy, Ecology, and Pathology. D. C. Erwin, S. BartnickiGarcia, and P. H. Tsao, eds. APS Press, St. Paul, MN.

15. Wood, B. W., Payne, J. A., and Grauke, L. J. 1990. The rise of the U.S. pecan industry. HortScience 25:594, 721-723. 